sciendo Порівняльна професійна педагогіка 8(4)/2018 Comparative Professional Pedagogy 8(4)/2018

DOI: $10.2478 /$ rpp-2018-0057

Senior Lecturer, VASYL OVCHARUK

Vinnytsia National Technical University, Ukraine Address: 95 Khmelnytskyi HWY, Vinnytsia, 21021, Ukraine

E-mail: vvovcharuk@gmail.com

\title{
HEALTH, HEALTH PRESERVATION AND HEALTH-PRESERVING COMPETENCY IN THE CONTEXT OF UKRAINIAN AND FOREIGN SCHOLARS' VIEWS
}

\begin{abstract}
The article deals with theoretical and historical analysis of Ukrainian and foreign scholars' views on such concepts as "health", "health preservation" and "health preserving competency". It is specified that the problem of health is considered by medical specialists, philosophers, sociologists, psychologists, teachers and, thus, is covered in many sociological, philosophical, educational, sociological and medical studies. It is found that this problem became particularly topical in the second half of the 20th century. Based on the analysis of educational researches and practical experience of scholars from many countries, it is clarified that there is a growing interest in the issues related to health and health preservation. The requirements for fostering and strengthening health have significantly increased, too. However, there is no clear definition of this concept. This is caused, first of all, by lack of generally accepted understanding of health preservation. Secondly, theoretical and pedagogical principles and methodological and technological aspects of health preservation are insufficiently developed. Thirdly, there are no scientific and practical recommendations and methods of fostering health preservation. The meaning of this concept has gradually changed, since at different times, in different cultures, the definition of health and its derivatives differ substantially. Nowadays, life and health are defined as the highest human values. They indicate civilization, which characterizes a general level of socioeconomic development of society and serves as the main criterion of expediency and efficiency of all, without exception, fields of state policy. It is concluded that health preserving space, as a field of activity, is a specially organized system aimed at achieving the goal of professional activity through ensuring preservation and restoration of its participants' health.

Keywords: health, health preservation, valeology, competency, concepts, critaria, indicators, technologies.
\end{abstract}

\section{INTRODUCTION}

In recent decades, the problem of health has become particularly acute, since the state of health serves as an indicator of spiritual, socioeconomic, medical and biological welfare of the population, a level of development and civilization of the country. It must be noted that teachers, along with sociologists and doctors, pay considerable attention to the problems related to choosing the way of life and preserving health. There is no doubt about the importance of differentiated approach to creating a healthy lifestyle in different segments of the population and social groups.

In the light of the need to enhance productive capacity of Ukraine and increase its gross domestic product (GDP), declare martial law and reduce the outflow of highly skilled personnel abroad, it is necessary, on the one hand, to assure proper working conditions and provide perks, and on the other hand, to foster future specialists' internal motivation and 
sciendo Порівняльна професійна педагогіка 8(4)/2018 Comparative Professional Pedagogy 8(4)/2018

need to preserve health, and, as a result, expediently use and increase their own physical, psychological and professional resources, which will lead to successful professional performance and personal development.

The problem of a modern person, his/her health and psychological harmony consists in the loss of integrity and communication. Thus, awareness and activities of primitive people were syncretic. In addition, people believed in animism (the presence of the soul in inanimate nature), danced, sang and performed rituals, which in itself included motor activity, and the above-mentioned beliefs acted as a powerful motivational resource. All this was supplemented by the need for high physical and psychological fitness, which was required for hunting and defending the territory from other tribes. In essence, a sense of integrity and communication (involvement in events and phenomena of the world) were the most ancient, relict conditions under which original awareness of health preservation was shaped.

\section{THE AIM OF THE STUDY}

The aim of the study is to analyze theoretically and historically Ukrainian and foreign scholars" views on such concepts as "health", "health preservation" and "healthpreserving competency.

\section{THEORETICAL FRAMEWORK AND RESEARCH METHODS}

Theoretical framework of research encompasses modern conceptions of pedagogy and methodology, definition-based analysis, the essence and content characteristics of core concepts that made it possible to explore the process of developing health-preserving competency. Consequently, the main goal of the category "health - health preservation competency", which includes such specific concepts as health, motor activity, health preservation, health-preserving technologies, valeological culture and educational space, was clarified. It was specidied that the problems on health, health preservation and healthpreserving competency were theoretically and historically analysed by many Ukrainian (I. Anokhina (2007), V. Balsevich (1990), M. Bobyreva (2008), B. Butenko (1988), V. Filinkov (2003), S. Kim (2005), P. Lesgaft (1987), B. Maksymchuk (2016; 2017), O. Moskovchenko (2008), N. Tamarskaya (2002), A. Verbytskyi (2008) et al.) and foreign (R. Bailey (2010), A. Hornby (2015), T. Hyland (2001), U. Jorgensen (2003), M. Karloven (1983), M. Knowles (1959), R. Kohen-Raz (1996), D. Kolb (1984), M. Lloyd (1925), D. McClelland (1973), E. Weiner (2008) et al.) scholars.

In the context of the above-mentioned aspects, health preservation is considered to be the main objective of education, especially higher education, which finalizes socialization and self-determination of the individual. It is clear that educators view health preservation and rehabilitation as the basis for enhancing the development of theoretical and practical abiliies in rehabilitation, which most naturally occurs in the mode of optimal motor activity.

While researching, such methods as theoratical and historical analysis, generalization and systematization were employed.

\section{RESULTS}

After Ukraine became independent in 1991, certain laws and specific provisions related to improving health of the population in the context of education and beyond it were adopted. The main ones are as follows: a) not related to education - the Law of Ukraine "On Health Preservation", the comprehensive programme "The Health of the Nation"; b) related to education - the Law of Ukraine "On Education" (1991), the Law of Ukraine "On Higher Education" (2014), the State National Program "Education" ("Ukraine in the 21st Century") (1993), the National Doctrine of Education Development in Ukraine (2002), 
the National Strategy for Education Development in Ukraine during 2012-2021; c) related to physical culture and rehabilitation - the Law of Ukraine "On Physical Culture and Sports" (1994), the State Programme for Development of Physical Culture and Sports in Ukraine (1994); d) related to educational and valeological issues affecting health of students and technical specialists - the Law of Ukraine "On Vocational Education", the Draft Concept of Development of Engineering and Teacher Education (2004).

Health is an invaluable asset not only for every person, but for society as a whole. During meetings or when saying goodbye to dear people, we wish them good and excellent health, because this is a basic condition and a guarantee of a full and happy life. Health helps us fulfill our plans, successfully solve basic life problems, overcome difficulties and significant overloads. Strong health, which is cleverly preserved and strengthened by the individual himself/herself, provides him/her with a long and active life (Bailey, 2010).

Therefore, a very important element in preserving one's own health is personal knowledge of health matters and harmfulness of certain factors and habits. However, the study shows that the concept of "health-preserving competency" has not been studied sufficiently, since it has emerged relatively recently in the context of competency-based approach launched in the USA in the 1970s. In addition, there is no definite definition of this concept.

D. McClleland (1973) believes that competence does not imply only professional skills, but also integral properties of a highly organized profession-oriented personality that allow him/her to perform professional duties most efficiently and solve any professional task creatively.

Studying the problem of fostering health-preseving competency of students requires that the main concepts constituting research terminology should be theoretically and historically analyzed. These concepts include health, healthy lifestyle, health preservation, health-preserving competency.

The very first theoretical views on health preservation reach antiquity and are based on philosophical thoughts of the ancient East. In the first European states (Ancient Greece and Rome), they cherished a cult of a healthy, beautiful and physically perfect body. The ancient Roman physician Hippocrates, who created a somewhat metaphorical, yet applicable, classification of human temperaments - choleric, sanguine, melancholic, and phlegmatic, first drew attention to a deterministic connection between mental and physical characteristics.

The ancient Chinese philosopher Confucius proclaimed the truth, which became the basis of many psychological, philosophical and valeological theories, namely "create yourself". In general, the whole philosophy of the ancient East is anthropological. Ibn Sina (Avicenna) first indicated the connection between physical and mental aspects in preserving health in medicine. The scientist considered the range of behaviour and activity, namely tolerance - spirituality - hygiene - activity - healthy lifestyle, to be the conditions of health preservation.

Even when certain sciences developed outside philosophy, health (as a value and a component of personality) continued to remain an object of ideological theories. The prominent German philosopher G. W. F. Hegel carried out important anthropological observations within the framework of natural philosophy, which can be the basis of the principles of valeological and physical development. The philosopher defended organic integrity of all the natural things, including the indivudual, whose essence consists in the 
sciendo Порівняльна професійна педагогіка 8(4)/2018 Comparative Professional Pedagogy 8(4)/2018

unity of objective and subjective, theoretical and practical aspects. Nature develops gradually, with the next level deploying the truth of the previous one (gradualness and integrity of the activity).

In the era of the Enlightenment, the idea of a natural correspondence in shaping and preserving volition, character, practical skills, conditioning and health became rather common acquired in Europe (J.-J. Rousseau, Voltaire, J. Locke). Scientists suggested moving from education and training to strengthening and improving, that is, from valeology to physical culture.

In the Russian Empire's war with Napoleonic France, Russian soldiers were taught to develop the principles of physical culture, which were also considered as a means of fostering volition and military build. In the end of the 19th century - the early 20th century, P. Lesgaft started to promote physical culture. In accordance with its main principles, a success of life largely depends on conscious and flexible physical activity (Lesgaft, 1987). The following methodological concept has became the key basis of physical education within the framework of the then materialism: unless one trains, develops and improves, he/she degrades.

In the early 20th century, a holistic paradigm of natural organisms and systems reemerged. Thus, M. Lloyd (1925) proves that natural objects (people) are holistic substances both within themselves and in relation to nature. These are material subjects that are self-regulating and self-evolving. Therefore, physical activity does not require special stimulation, since it is immanent. Such anthropological theories became particular popular in Western Europe. C. Hall and G. Lindsay (1997) believe that a person or any natural structure cannot be studied partially, because they possess such characteristics of integrity, coherence and integrity.

S. Kim (2005) suggests that the term "health preservation" should be replaced with "health creation". Indeed, health preservation as a combination of daily life activities and specially directed health-creating activity determines social welfare in the process of selfrealization while preserving vital potential of health. It must be noted that healthy lifestyle stands out as a synonymous and at the same time complementary concept to "health preservation".

Nowadays, foreign anthropology largely promotes Kolb's experiential learning theory. It is primarily applied to social work and consists in a relatively defined cycle of health creation. The first stage of a training valeological period involves acquisition of personal experience and the second one - reflexive learning and observation. The results obtained during the two stages should form a certain concept, based on which it is possible to conduct different experiments, solve contextual situations, valeological tasks and, as a result, organize professional valeological practice (Kolb, 1984; Maksymchyk, 2017).

Various aspects of fostering health preservation and healthy lifestyles were highlighted by different scholars from Canada, the United States, the UK, Sweden. They highlighted the problem of hypodynamia and the importance of physical activity and its connection with quality of life (Hornby, 2005; Hyland, 2001; Karloven, 1983).

Ukrainian educational researches pay particular attention to theoretical and practical aspects of valuable approach to fostering health (D. Davydenko, A. Ivaniushkin, V. Petlenko), healthy lifestyle (R. Raievskyi, V. Volkov), various aspects of cultivating culture of health in future specialists during physical education (S. Bielykh, T. Kyrychenko, V. Yakovliev) and health-preserving competency in students by means of physical education (M. Borisov, L. Hrytsiuk, A. Liakisheva, D. Voronin) (Maksymchuk, 2016). 
N. Tamarskaya (2002) indicates that the essence of health preservation is manifested in the organization of preventive measures and the use of health-preserving technologies by those who are aware of the laws of health preservation I. A. Anokhina (2007) considers health preservation as willingness to independently solve problems associated with strengthening and preservation of health, both one's own and others.

In relation to the above-mentioned views, various scholars have focused on the problems of cultivating students' activity and negative effects of educational and noneducational conditions and prospects for their optimization since the early 2000s.

Nowadays, general concepts of pedagogical and, more broadly, educational conditions for fostering health of future specialists are developed by such scholars as R. Hurevych, N. Kuzmina, O. Lavarnenko, L. Mitina, I. Zimniaia et al. Psychological and valeological aspects of health are studied by G. Ivanov, V. Prykhodko, I. Saluk, M. Sevriuk, M. Selezinka, I. Smoliakova, L. Stoliarenko. The aspects of destructive influence of professional conditions on students' health are explored by O. Domashenko, V. Filinkov, U. Jorgensen, L. Yevsieiev, Y. Zentsova et al. Optimization of educational conditions and improvement of students' health through physical education are analyzed by R. Bailey, V. Baronenko, L. Green, O. Hladoshchuk, H. Hryban, R. Vakhitov et al.

It is proved that a low level of future technical specialists' health negatively affects: a) productivity of learning and professional performance; b) motivation and creative activities; $c$ ) the main professional qualities of an engineer (concentration, rational approach, responsibility, personal safety); d) productivity and, as a result, competitiveness in the labour market (Filinkov, 2003). Thus, the above-mentioned views create theoretical basis for teachers and professional motivation for all the participants in the education process in order to include health preservation into the activities of other spheres.

It should be borne in mind that a medical concept of health prevailed in science for a long time. It implied the absence of diseases and viewed a disease as a certain autonomous essence. However, since the 1970s, diseases and health have been regarded as certain subjective states. Health is a functional state of the body and the psyche, which enables viability, development, reproduction, creative activity. The essence of health is confirmed by scientific and people's observations. According to the latter, health is the greatest value. Modern biophysical scientific approach, in turn, determines health as a dynamic balance, homeostasis of organs, systems and their functions in interaction with each other and with the external environment.

E. Weiner (2008) considers the concept of "health" as a fundamental factor in social development and even economic progress and proposes the concept of "public health". Personal health is its elemental component, since it not only constitutes the health of the community but also is compressed by social culture, values, political and other influences. The educator indicates that public health is a social, economic and demographic resource. Its main function consists in human reproduction and comprehensive development, beginning from a personal or family level.

B. Maksymchuk (2017) states that foreign medicine and valeology view an empirical component of measuring, assessing and preventing stressful, technogenic and other external factors as extremely important and topical.

R. Kohen-Raz, M. Himmelfarb, \& S. Tzur (1996) suggest that one should not rely on subjective assessment of the individual's valeological state and better apply a general neurological method of stabilography, which, by means of special measurements, 
sciendo Порівняльна професійна педагогіка 8(4)/2018 Comparative Professional Pedagogy 8(4)/2018

determines general physiological, neurological and valeological state. The essence of this method consists in measuring coordination of movements and assessing the state of the vestibular apparatus by means of medical equipment, since it shows the state of exhaustion, fatigue and work capacity. The prognostic results are the following: physical stability and stress resistance, endurance, self-regulation, etc.

M. Knowles, \& H. Knowles (1959) indicate that competency is the ability to professionally perform one's duties under changing conditions, which require that the individual should engage in life-long learning and interact with others within open information environment.

The views of Ukrainian researchers on the essence of health-preserving technologies are aimed at general "background" orientation towards preserving and improving quality of life of the participants in the education process, as well as organizing special rehabilitation activities; pedagogically expedient actions, techniques, means, which assure learning, development and further personal and professional activity of the individual provided thet he/she is ready to preserve and enhance psychophysiological resources.

Some foreign researchers believe that a health-saving technology is the basic pedagogical tool of health preservation, since it is a set of specific knowledge, methods, practices and techniques, which can solve the following tactical tasks: to assess (diagnose), to organize and optimize a fragment of the educationa process (within or outside the educational institution) in order to prevent a decrease, to preserve the existing condition and assure development of physical, mental and social potential of the individual (Moskovchenko, 2008).

Having analyzed relevant researches by Ukrainian and foreign scholars on health and health preservation and the ways of its assessment and contextualized the gathered information on the example of future technical specialists' professional training, it is possible to distinguish the following criteria for assessing the acquired health-preserving competency: axiological (the presence of valeological values and their place in the structure of personality), technological (the presence of knowledge, skills, techniques and means for solving valeological problems), creative (creative activity, the ability to take non-standard decisions in difficult situations), reflexive (the ability to self-analyze and adjust valeological technologies to personal needs), integrative (readiness to apply partial competencies, presented in the above-mentioned criteria).

\section{CONCLUSIONS}

Therefore, based on the analysis of educational researches and practical experience of scholars from many countries, it is clarified that there is a growing interest in the issues related to health and health preservation. However, there is no clear definition of this concept. This is caused, first of all, by lack of generally accepted understanding of health preservation. Secondly, theoretical and pedagogical principles and methodological and technological aspects of health preservation are insufficiently developed. Thirdly, there are no scientific and practical recommendations and methods of fostering health preservation. It is concluded that health preserving space, as a field of activity, is a specially organized system aimed at achieving the goal of professional activity through ensuring preservation and restoration of its participants' health.

Further researches on health, health preservation and health-preserving competency should take into consideratiob the process of shaping a valuable approach to fostering health and cultivating physical culture of students. 
sciendo Порівняльна професійна педагогіка 8(4)/2018 Comparative Professional Pedagogy 8(4)/2018

\section{REFERENCES}

1. Anokhina, I. A. (2007). Priobshchenie doshkolnikov $k$ zdorovomu obrazu zhizni. Ulianovsk: UIPK-PRO.

2. Bailey, R. (2010). Physical education for learning: a guide for secondary schools. London: Continium International Publishing Group.

3. Balsevich, V. K. (1990). Fizicheskaia podgotovka v sisteme vospitaniia kultury zdorovogo obraza zhizni cheloveka (metodologicheskii, ekologicheskii i organizatsionnyi aspekty). Teoriia i praktika fizicheskoi kultury, 1, 14-22.

4. Bobyreva, M. M. (2008). Sovershenstvovanie metodiki professionalno-prikladnoi fizicheskoi podgotovki studentov meditsinskikh vuzov. (Avtoref. diss. kand. ped. nauk). Kazakhskaia akademiia sporta i turizma, Alma-Aty.

5. Butenko, B. I. (1988). Novoe v ponimanii zdorovia. Teoriia $i$ praktika fizicheskoi kultury, 7, 19-22.

6. Filinkov, V. I. (2003). Systema profesiino-prykladnoi fizychnoi pidhotovky fakhivtsiv mashynobudivnoi promyslovosti. (Dys. kand. fiz. vykh.). Lvivskyi derzhavnyi instytut fizychnoi kultury, Lviv.

7. Green, L. W. (1984). Health education models. In J. Matarazzo, S. Weiss, J. Herd, N. Miller, \& S. Weiss, Behavioral Health: A Handbook of Health Enhancement and Disease Prevention (pp. 160-184). New York, NY: Wiley.

8. Hall, K. S., \& Lindsay, G. (1997). Teorii lichnosti. Moskva: KSP+iu

9. Hornby, A. S. (2005). Oxford advanced learning dictionary of current English. (7th ed.). Oxford: Oxford University Press.

10. Hyland, T. (2001). Book review of competency based education and training: a world perspective by A. Arguelles and A. Gonczi (eds.). Journal of Vocational Education and Training, 53 (3), 487-490.

11. Jorgensen, U. (2003). Fremtidige profiler i ingenierarbejde og uddannelse. Copenhagen: IDA.

12. Karloven, M. J. (1983). Physical activity and health. Sports and Exercise Medicine in Finland, 2, 4-9.

13. Kim, S. V. (2005). Valeologicheskaia bezopasnost obrazovaniia. Resursy pedagogicheskikh sistem. Sankt-Peterburg: SPbGUEF.

14. Knowles, M. S., \& Knowles, H. F. (1959). Introduction to group dynamics. Chicago, IL: Association Press.

15. Kohen-Raz, R., Himmelfarb, M., \& Tzur, S. (1996). An initial evaluation of work fatigue and circadian changes as assessed by multiplate posturography. Perceptual \& Motor Skills, 82, 547-562.

16. Kolb, D. A. (1984). Experiential learning: experience as the source of learning and development. Englewood Cliffs, NJ: Prentice Hall.

17. Lesgaft, P. F. (1987). Rukovodstvo po fizicheskomu obrazovaniiu detei shkolnogo vozrasta. Moskva: FiC.

18. Lloyd, M. C. (1925). Life, mind, and spirit: emergent evolution. London: Williams and Norgate.

19. Maksymchuk, B. (2016). Forming future specialists' valeological competency: theoretical analysis of domestic and foreign scholars' views. Comparative Professional Pedagogy, 6 (4), 47-54. 
20. Maksymchuk, B. A. (2017). Teoretychni ta metodychni osnovy formuvannia valeolohichnoi kompetentnosti maibutnikh uchyteliv u protsesi fizychnoho vykhovannia. (Dys. d-ra ped. nauk). Vinnytskyi derzhavnyi pedahohichnyi universytet im. Mykhaila Kotsiubynskoho, Vinnytsia.

21. McClelland, D. C. (1973). Testing for competence rather than for "intelligence". American Psychologist, 28, 1-14.

22. Moskovchenko, O. N. (2008). Optimizatsiia fizicheskikh nagruzok na osnove individualnoi diagnostiki adaptivnogo sostoianiia u zanimaiushchikhsia fizicheskoi kulturoi $i$ sportom (s primeneniem kompiuternykh tekhnologii). (Avtoref. diss. kand. ped. nauk). Politekhnicheskii institut Sibirskogo federalnogo universiteta, Moskva.

23. Tamarskaia, N. V., Rusakova, S. V., \& Gagina, M. B. (2002). Upravlenie uchebno-vospitatelnym protsessom v klasse (zdorove sberegaiushchii aspekt). Kaliningrad: KGU.

24. Weiner, E. N. (2008). Valeologiia. Moskva: Nauka.

25. Verbitskii, A. A., \& Ermakova, O. B. (2008). Shkola kontekstnogo obucheniia kak model realizatsii kompetentnostnogo podkhoda v obshchem obrazovanii. Pedagogika, 7 , $12-17$. 